\title{
Strength testing of rock and ground anchor rods under static and dynamic loads
}

\begin{abstract}
Various types of anchor rods are commonly used for rock mass and soil reinforcement, produced either as full-section steel rods or tubes with threads along their entire length, which are used for the injection of liquid binders. This paper presents the methodology and sample results of strength tests of self-drilling injection anchor rods with R32 rope threads. Such rods are used both in underground mining and in geoengineering under static and dynamic (impact) loads. The results of tests of injection micropiles with trapezoidal thread diameters in the range of T51-T111 mm, used mainly in geoengineering, are provided as well. This paper also presents the basic requirements for the fatigue loading of nails and injection micropiles used in geoengineering, based on standards and the European Assessment Document (EAD), applicable in the European Union.
\end{abstract}

Key words: rock bolts, soil nails, injection micropiles, resistance to static and dynamic load, fatigue tests

\section{INTRODUCTION}

Various types of anchor rods are commonly used for rock mass and soil reinforcement, produced either as full-section steel rods or tubes with threads along their entire length, which are used for the injection of liquid binders. The increase in deep mine outputs consequently entails the growing significance of rock bolting, performed primarily in order to reinforce the rock mass and increase its self-supporting capacity. Rock bolt support is not only used under the conditions of dynamic loads generated by rock mass tremors and rock bursts [1], but also by dynamic impacts of the means of transport [2]. Anchors are mainly exposed to dynamic tensile impact $[3,4]$ and shear [5] during rock mass tremors. The economic factor also plays a significant role in the increasing popularity of rock bolting, as this form of support is less expensive compared to steel arch support systems and more convenient from the perspective of transportation. Modern anchors are characterized by great resistance to not only static loads, but also dy- namic impact loads. Requirements for the performance of geotechnical works are included in the standards for nails [6] and micropiles [7], which are mainly used for soil strengthening [8-10], foundation of building structures and tunnels stabilization [11]. Therefore, the anchor rods, nuts, coupling sleeves and other elements, constituting the complete reinforcement system, are produced using steel materials with high mechanical properties confirmed through strength testing, primarily under static and fatigue loading. This paper presents the methodology and sample results of strength tests of self-drilling injection anchor rods, used both in underground mining and in geoengineering, under static and dynamic impact loading. The results of static strength tests of injection micropiles, used primarily in geoengineering, are provided as well. This paper also presents the basic requirements for the fatigue loading of nails and injection micropiles used in geoengineering, based on standards and the European Assessment Document (EAD) [12, 13], applicable in the European Union. 


\section{TEST METHODOLOGY}

\subsection{Tests under static loading}

The basic anchor rod strength parameters are tensile strength $R_{m}$, upper $R_{e H}$ and lower $R_{e L}$ yield stress or the proof stress $R_{0.2}$, total percent elongation $A_{g t}$ at maximum force and total percent elongation at break $A_{t}$. Tensile testing of the samples of steel used to produce the rods is not reliable. This is primarily due to the fact that the mechanical properties of the steel undergo changes during rod production as a result of processing. It is therefore necessary to subject the end product, i.e. the anchor rod, to tensile testing, which is defined in standard PN-EN ISO 6892-1 [14]. The results of such studies, although carried out under slightly different conditions, are presented in the work [15].

Tests of such rods, as well as of rods coupled by means of couplers, are conducted in a static testing machine with a maximum tensile force of $5000 \mathrm{kN}$ (accuracy class 1). Figure 1 shows a schematic of a static test. The tested anchor rod (3) is mounted between the machine crossbeams and locked on both sides by means of two nuts (2). The force measurement is carried out by force sensor (1) mounted on the fixed crossbeam and the measurement of the dis-

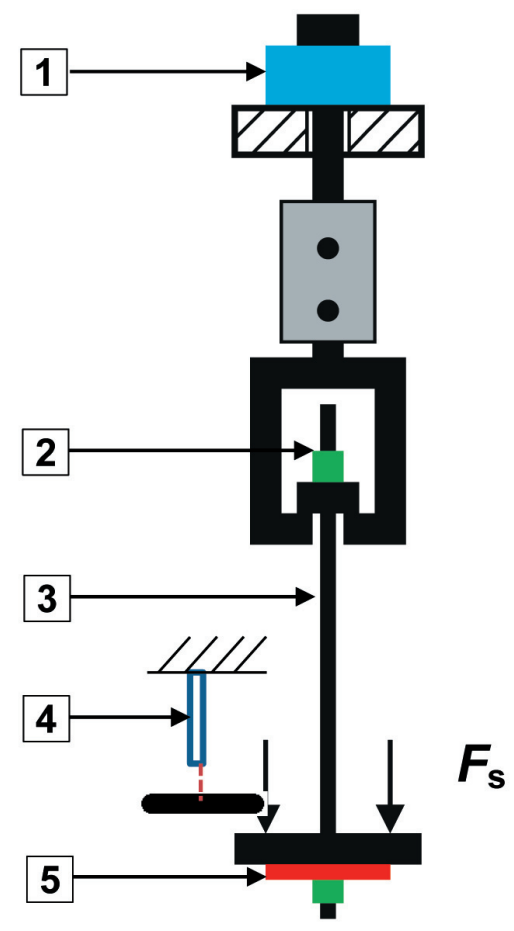

Fig. 1. Load case for an anchor rod under static

loading: 1 - force sensor, 2 - anchor nut, 3 - anchor rod, 4 - displacement sensor, 5 - anchor washer placement is carried out with the use of a line sensor (4) attached to the movable crossbeam to which the force $F_{s}$ is applied. The initial measurement length $L_{o}$ is typically $1000 \mathrm{~mm}$. The test consists in loading the tested rod with a tensile force $F_{s}$ until rupture. The tensile speed is determined on the basis of the stress increase rate (method B in the PN-EN ISO 6892-1 [14]), that is $6-60 \mathrm{MPa} \cdot \mathrm{s}^{-1}$. During the test, the loading force $F_{S}$ and the elongation of the rod $\Delta L$ are recorded.

The loading force and rod elongation are recorded during the test. The rod strength parameters are determined using software developed at the GIG Laboratory of Mechanical Devices Testing, based on standard PN-EN ISO 6892-1 [14]. The software calculated those parameters on the basis of measurement data saved in an ASCII code file and information about the cross-sectional area of tested sample $S_{o}$ and the initial measurement length $L_{o}$. The results are presented in a graphical (tensile diagram) and tabular form.

\subsection{Tests under dynamic impact loading}

The method for anchor testing under dynamic loading according to standard ASTM D7401-08 [16] consists in the free fall (by gravity) of a ram of a mass $m$ from a given height $h$ onto the anchor rod end (Fig. 2).

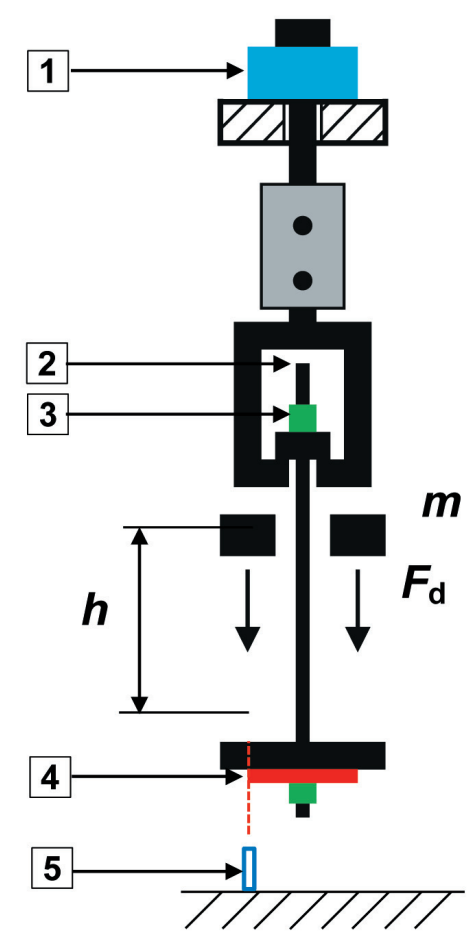

Fig. 2. Load case for an anchor rod under dynamic impact loading: 1 - force sensor; 2 - anchor rod;

3 - anchor nut; 4 - anchor washer; 5 - displacement sensor 
The force measurement is carried out by means of a force sensor (1) mounted on the fixed crossbeam and the displacement measurement is carried out by a laser sensor (5) attached to the ground, which measures the displacement of the end of the bold rod.

The test result is deemed positive if the anchor rod transfers a load of an energy and impact velocity declared by the manufacturer without failure.

According to the ASTM D7401-08 standard [16], the initial energy of the impact against the tested rod, corresponding to the potential energy $E_{p}$, is calculated using the following formula:

$$
E_{p}=m g h
$$

whereas the velocity $v$ of the impact against the tested rod is calculated as follows:

$$
v=\sqrt{2 g h}
$$

where:

$$
\begin{aligned}
h & -\operatorname{ram} \text { free fall height }[\mathrm{m}], \\
m & -\operatorname{ram} \text { mass }[\mathrm{kg}], \\
g & - \text { gravitational constant } 9.81\left[\mathrm{~m} / \mathrm{s}^{2}\right] .
\end{aligned}
$$

During testing, the dynamic loading force $F_{d}$ is measured by means of a strain gauge force sensor (class 0.5), whereas the anchor elongation $L_{d}$ is measured by a laser sensor $(0.1 \% \mathrm{~mm}$ resolution, $0.25 \%$ linearity error) with a minimum sampling rate of about $f=10 \mathrm{kHz}$ (as required by standard ASTM D7401-08 [16]). However, the experience of the GIG Laboratory of Mechanical Devices Testing reveals that in order to better capture the character of the dynamic load $F_{d}$ wave variations, the minimum sampling frequency during testing should equal $f=19.2 \mathrm{kHz}$. The sensors are connected to a measuring amplifier cooperating with a computer that registers the measurement data. The measuring amplifier is equipped with 24-bit analog-to-digital converters and the measurement data are transferred in a 4-byte form ( 3 bytes describing the measured value and 1 status byte).

\subsection{Tests under dynamic fatigue loading}

Anchor tests under dynamic fatigue loading are performed according to [12, 13]. The test is performed in a testing machine with a constant load frequency no greater than $30 \mathrm{~Hz}$, at a constant upper load of $65 \%$ of the anchor rod characteristic strength in this case it is the yield force $F_{p 0.2}$, which must first be determined during tensile rod testing under static loading. The range of loads $\Delta F_{p}=F_{z \max }-F_{z \min }$ must be maintained on a constant level for the entire duration of the test. This corresponds to a stress amplitude of $80 \mathrm{MPa}$ in the nominal cross section of the tested rod. The full test consists of 2 million load cycles. Figure 3 presents the test scheme. The tested anchor rod (3) is fixed between the machine crossbeams and is locked on each side with nuts (1). The axiality of the anchor rod is ensured by the washers (4). Force measurement is performed by means of a strain gauge force sensor (2)

The sample must be tested in a manner precluding secondary oscillations (resonance). It is also important for the sample to be free of filling material. It is essential to maintain a constant vibration amplitude and count the number of cycles during the test. The condition of the tested elements must be inspected after testing whether cracking or deformation can be observed.

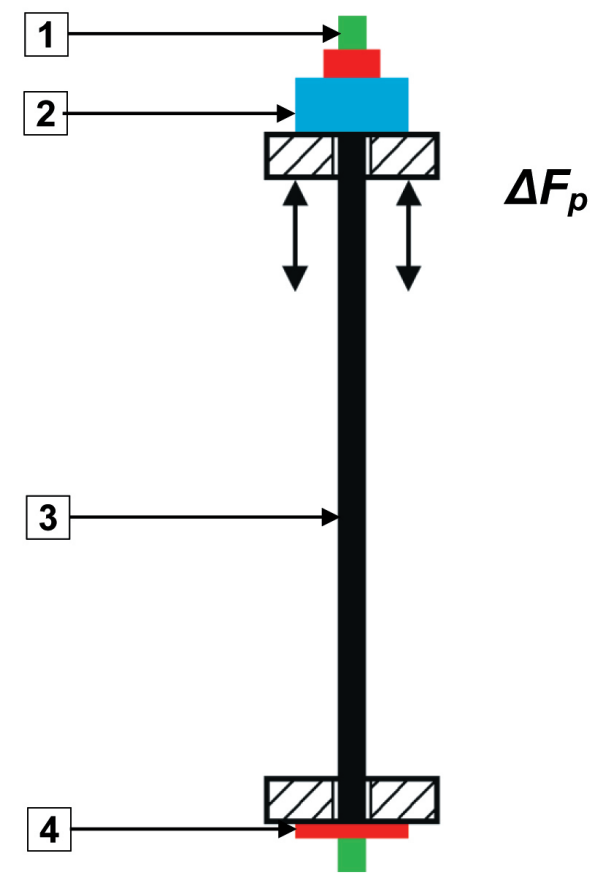

Fig. 3. Load case for an anchor rod under dynamic fatigue loading: 1 - anchor nut, 2 - force sensor, 3 - anchor rod, 4-anchor washer

\section{TEST RESULTS}

\subsection{Results of tests under static loading}

The basic test of an anchor rod under static load is the tensile test. On the basis of this test, the maximum tensile strength $R_{m}$, upper $R_{e H}$ and lower $R_{e L}$ yield strength or proof stress $R_{0,2}$, total percent elongation $A_{g t}$ at maximum force and total percent elongation $A_{t}$ at break are determined. 
The tests under static loading encompassed anchor rods with $\mathrm{R} 32$ rope threads and injection micropiles with coupling elements (Fig. 4).

Figure 5 presents an example R32 self-drilling rock anchor rod tension chart under static loading.

The anchor rod broke at force $F_{s \max }=366 \mathrm{kN}$.

Figures 6-8 present example T51, T76 and T111 injection micropile rod tension charts under static loading.
An example picture of a steel rod with a coupling sleeve and nuts in a testing machine with a range of up to $5000 \mathrm{kN}$ during tensile testing under static loading is presented in Figure 9. Coupling sleeve allows to connect the anchor rods or micropiles together in order to extend them. Figure 10 demonstrates an anchor rod after a tensile test.

a)

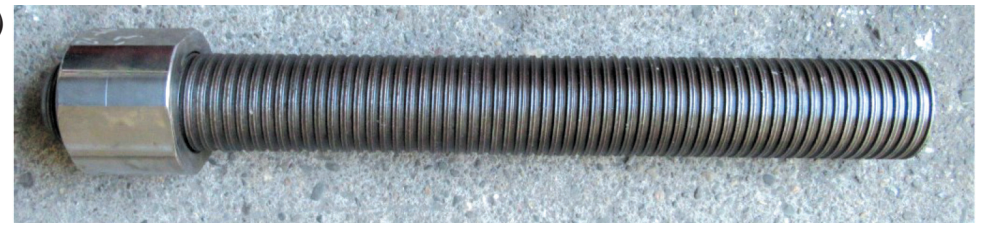

b)

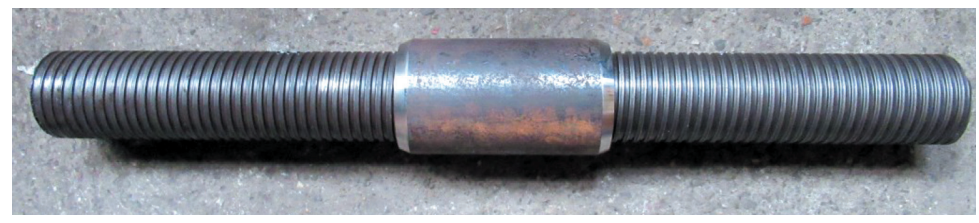

Fig. 4. Example view of an injection micropile with a nut (a) and two sections of an injection micropiles connected with coupling sleeve (b)

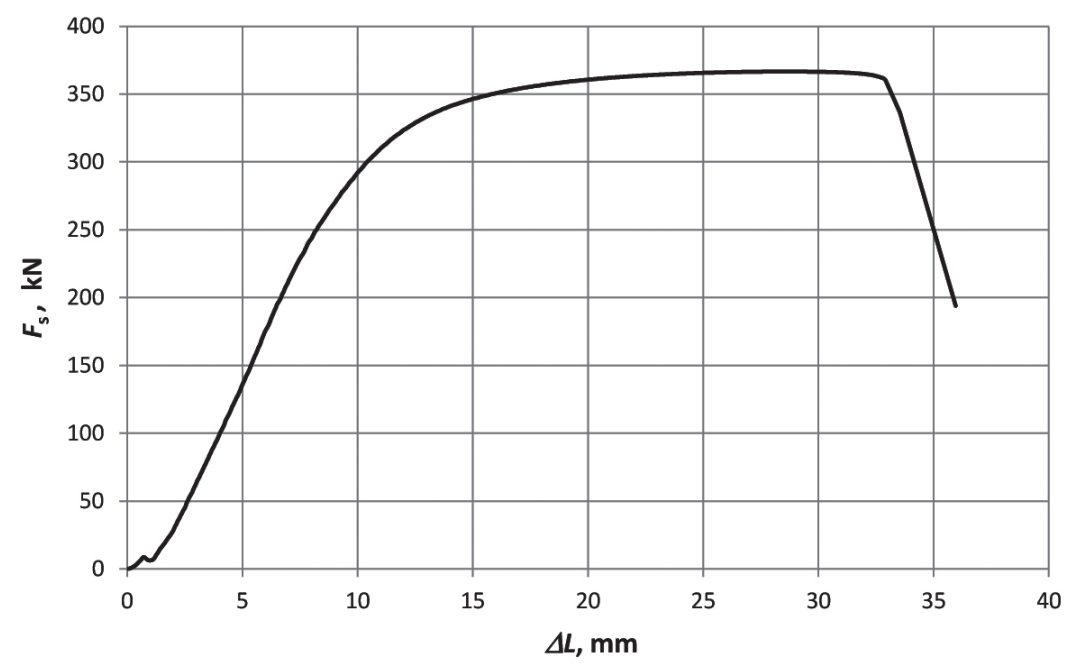

Fig. 5. R32 anchor rod tension chart

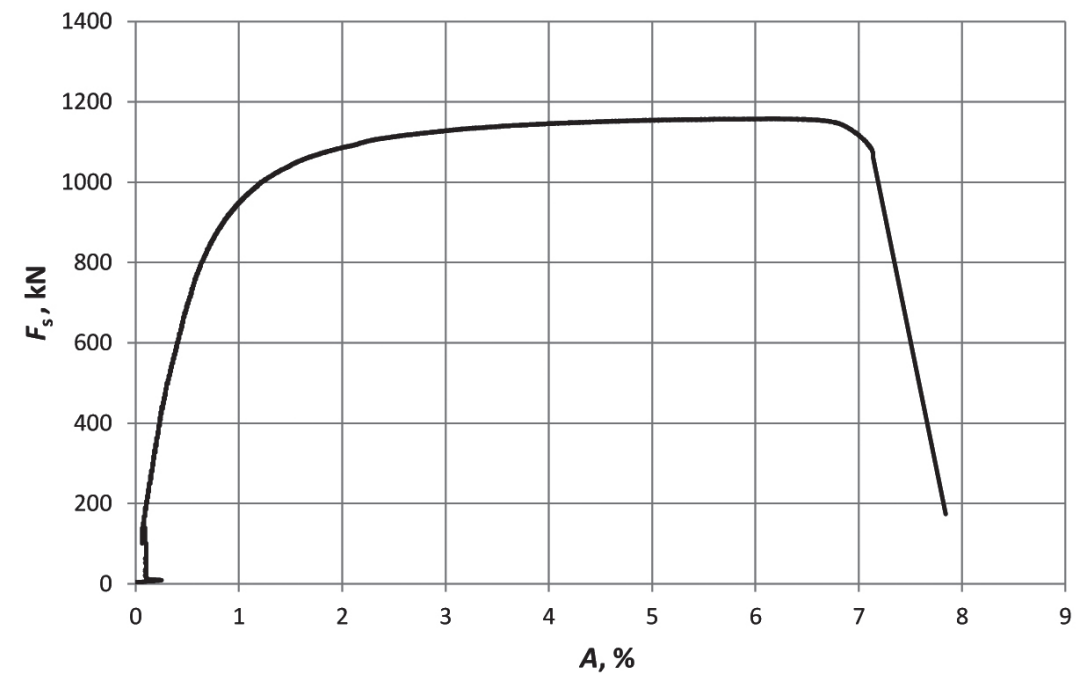

Fig. 6. $T 51$ anchor rod tension chart $\left(F_{\text {smax }}=1159 \mathrm{kN} ; A_{g t}=6.2 \%\right)$ 


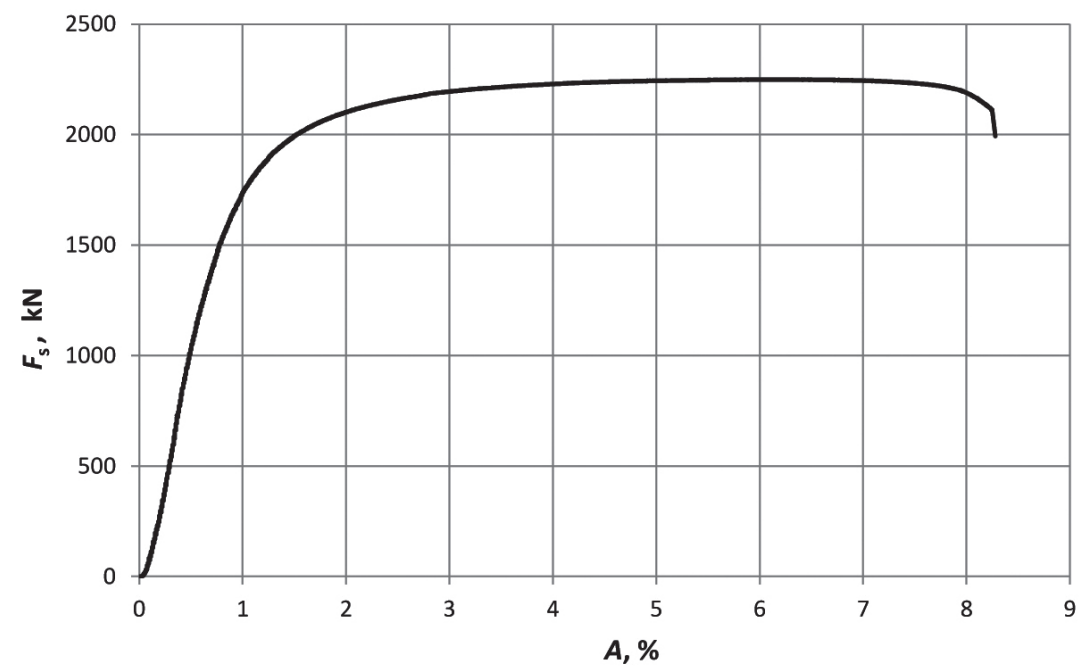

Fig. 7. T76 anchor rod tension chart $\left(F_{\text {smax }}=2250 \mathrm{kN} ; A_{g t}=6.0 \%\right)$

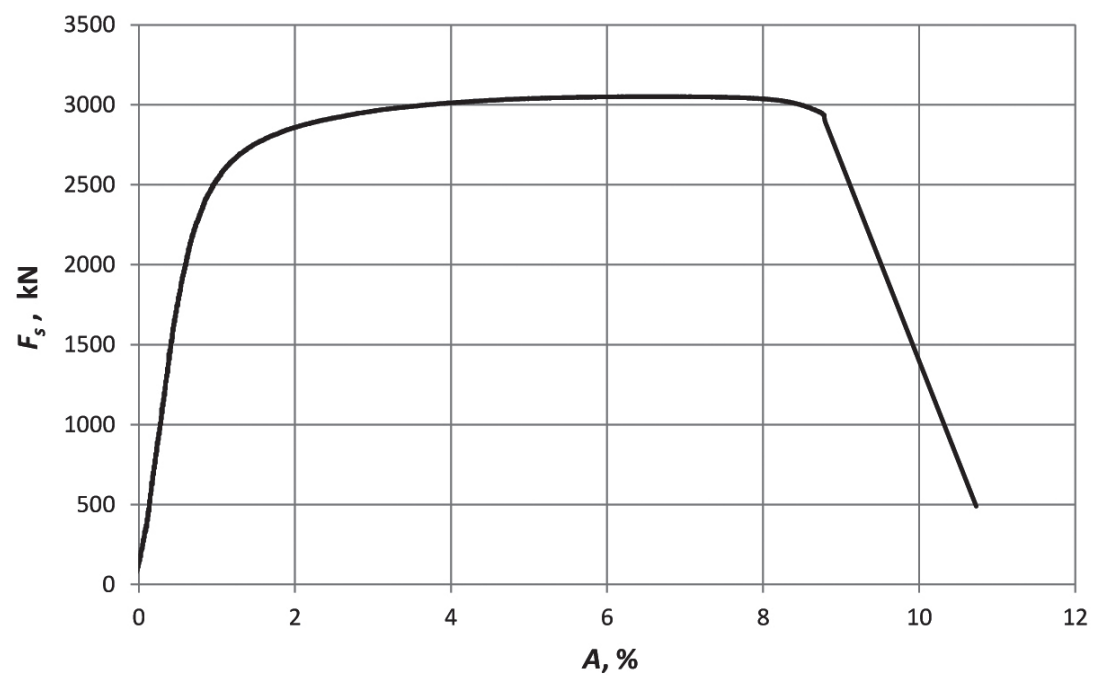

Fig. 8. $T 111$ anchor rod tension chart $\left(F_{\text {smax }}=3052 \mathrm{kN} ; A_{g t}=6.4 \%\right)$

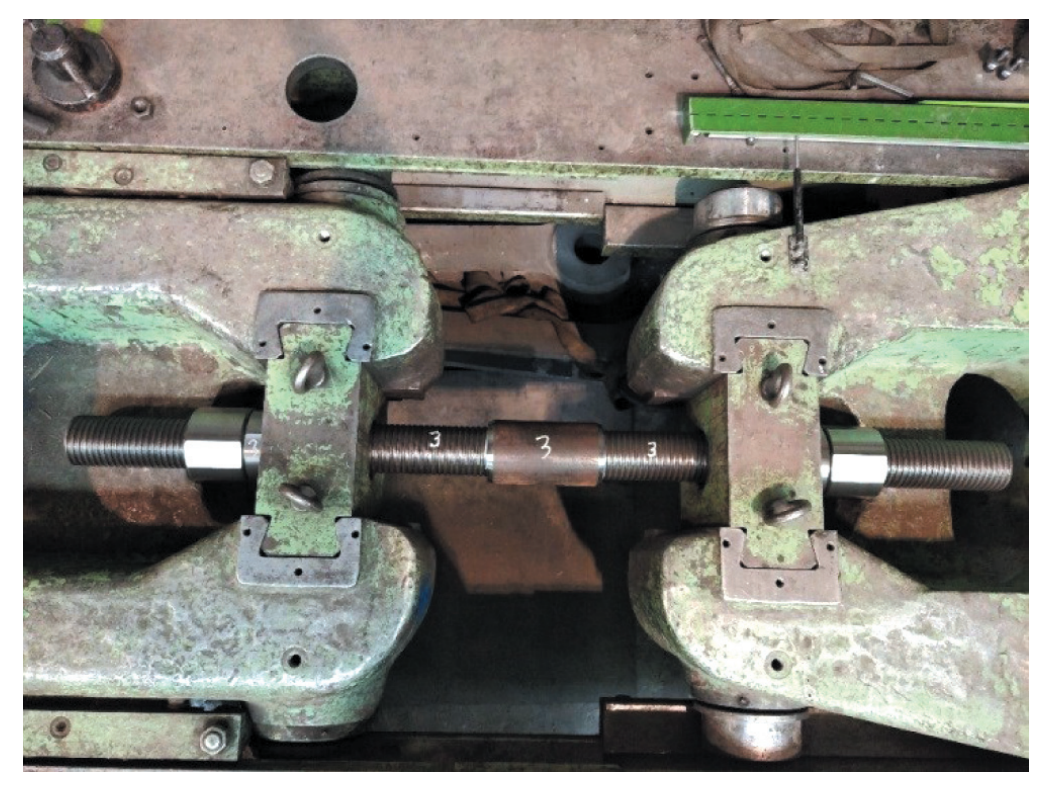

Fig. 9. Rod and coupling sleeve during tensile testing in a testing machine with a range of up to $5000 \mathrm{kN}$ 


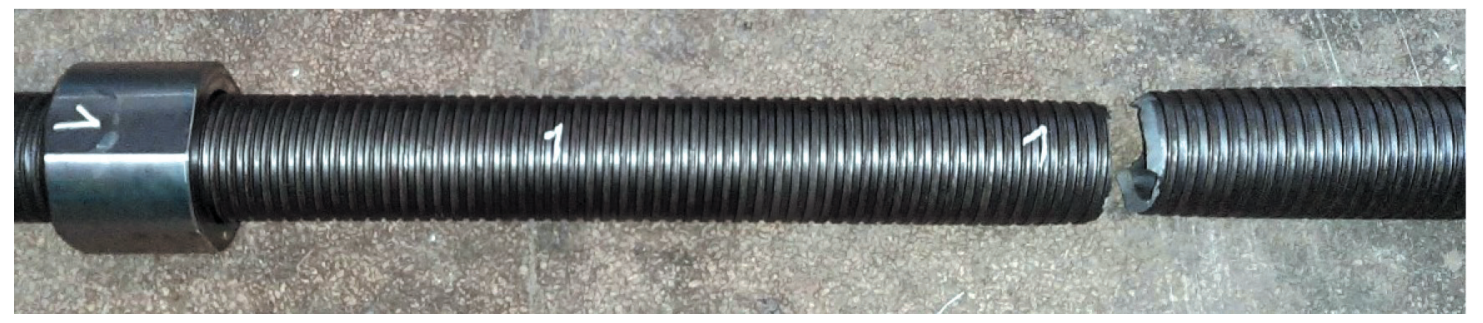

Fig. 10. Ruptured T111 anchor rod after a tensile test

\subsection{Results of tests under dynamic impact loading}

The tests encompassed self-drilling anchors with $\mathrm{R} 32$ rope threads, equipped with steel square washers with dimensions of $200 \mathrm{~mm} \times 200 \mathrm{~mm} \times 12 \mathrm{~mm}$. The tests inspected the anchor rod resistance to loads of an impact energy $E_{p}=30 \mathrm{~kJ}$ and impact velocity of about $5 \mathrm{~m} / \mathrm{s}$ (test parameters are calculated according to formulas 1 and 2). A ram of a mass $m=1950 \mathrm{~kg}$ lowered onto the anchor from a height $h=1560 \mathrm{~mm}$ was used during testing; consequently, the anchor was struck with an impact velocity $v=5.5 \mathrm{~m} / \mathrm{s}$. An example course of dynamic force $F_{d}$ as a function of time $t$ obtained during a test is presented in Figure 11.

The anchor transferred the impact load, the energy of which was $30 \mathrm{~kJ}$, without failure. Damped vibrations generated as a result of the ram rebounding from the anchor washer are visible in Figure 11a. Figure 11b presents the first load impulse, when the anchor rod was subjected to the maximum load $F_{d \max }=410 \mathrm{kN}$ and underwent the maximum elongation $L_{d \max }=119 \mathrm{~mm}$. a)

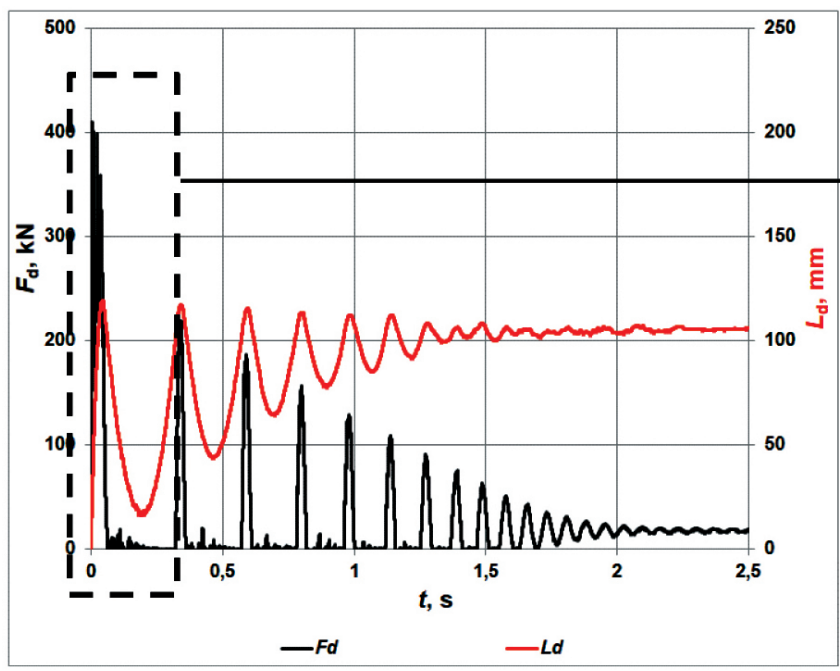

b)

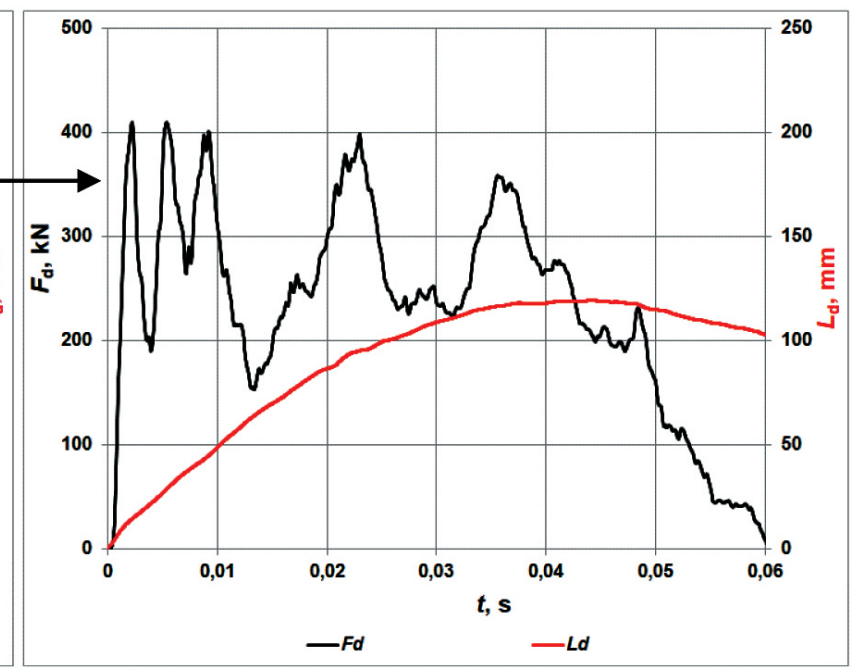

Fig. 11. Example course of dynamic force $F_{d}$ as a function of time tobtained during a test $a$ - full course of the test, $b$ - first load impulse

The remaining load impulses, resulting from consecutive, minor collisions of the ram against the anchor washer, result in no plastic deformation of the rod and therefore are not subjected to analysis.

\subsection{Results of tests under dynamic fatigue loading}

The tests under dynamic fatigue loading encompassed anchor rods with $\mathrm{R} 25$ rope threads. The nomi- nal yield force $F_{p 0.2}$ is $150 \mathrm{kN}$, and the nominal cross section area $S_{o}$ is $300 \mathrm{~mm}^{2}$. The maximum cyclic load is $65 \%$ of $F_{p 0.2}$, i.e. $97.5 \mathrm{kN}$ at a load amplitude of $24 \mathrm{kN}$. The load frequency during testing was over $10 \mathrm{~Hz}$. An example picture of a steel rod in a testing machine during fatigue testing is presented in Figure 12, whereas Figure 13 demonstrates an example chart of cyclic force $F_{z}$ as a function of time $t$ obtained during a test. After the test, the anchor rod did now show any visible defects or cracks. 


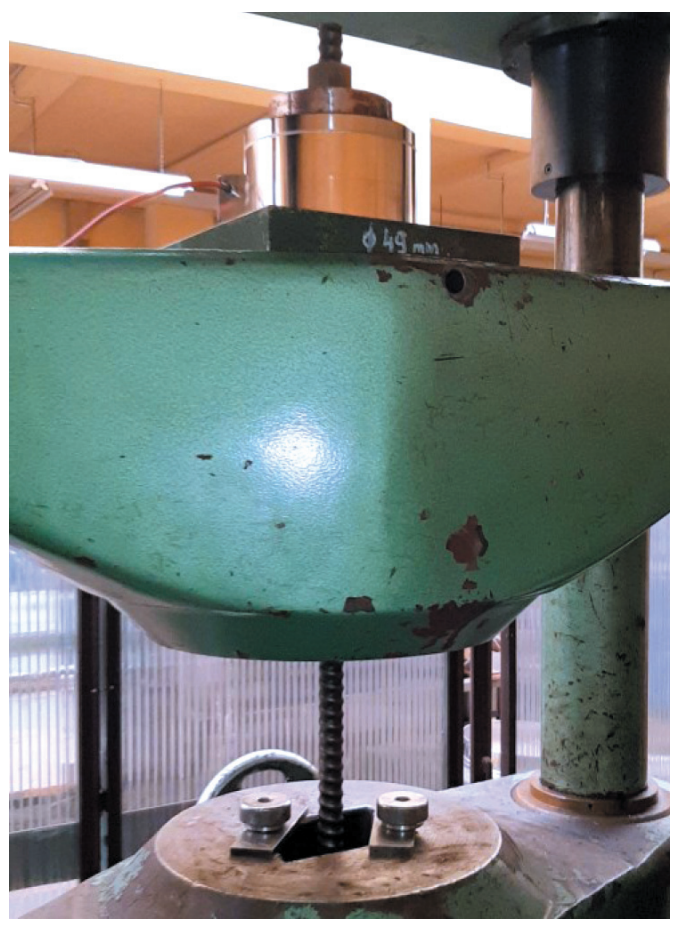

Fig. 12. Anchor rod mounted in a fatigue testing machine

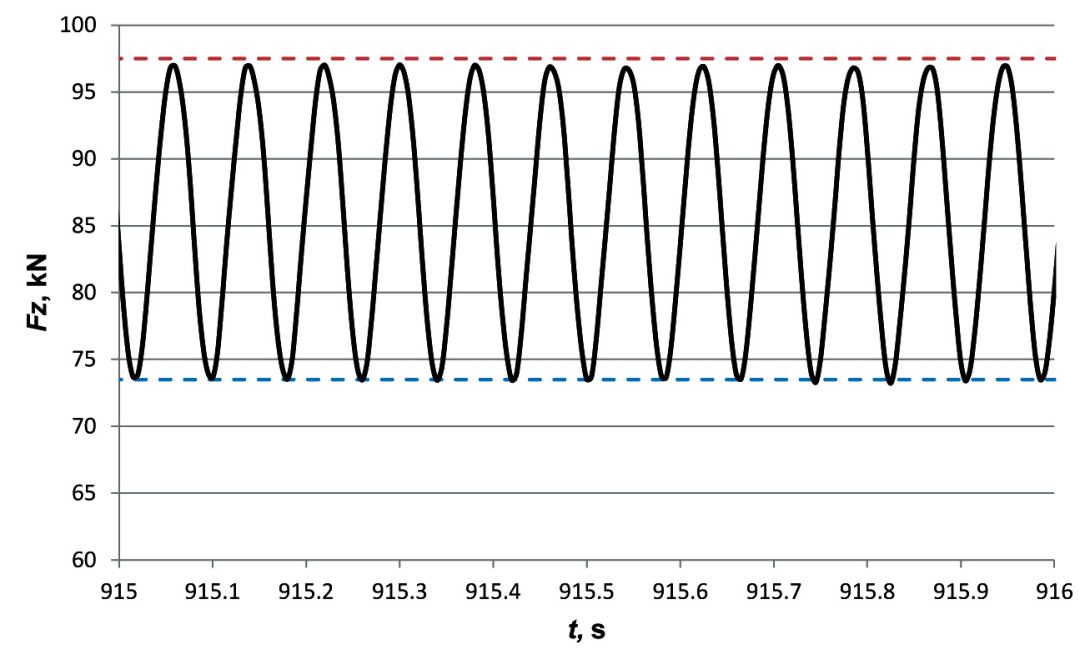

Fig. 13. Example course of cyclic force $F_{z}$ as a function of time tobtained during a test

\section{SUMMARY}

The methodologies for testing self-drilling injection anchors with $\mathrm{R} 32$ rope threads and injection micropiles with trapezoidal thread diameters in the range of T51-T111 $\mathrm{mm}$ presented in this paper factor in the typical operational characteristics of anchors under various conditions of their application. Naturally, these devices are tested under static loading as a standard practice, but the anchor, micropile and soil nail elements may be subjected to various load cases during their operation. Tests of micropiles and soil nails under dynamic fatigue loading are very important to determine their resistance to long-term cy- clic loads. However, it seems that, since they find common application in critical infrastructure building stabilisation, it should be considered that they may also be subjected to impact loads induced e.g. by earthquakes or tremors in post-mining areas.

The activities of the Central Mining Institute aim to improve personal safety and work conditions not only in underground mines, but also in post-mining areas, which often struggle with great difficulties in maintaining the stability of embankments, slopes, roads and other elements of structural engineering. For this reason, the micropile and soil nail testing is planned to be expanded with fatigue and impact tests in the future. 


\section{References}

[1] Li C.C.: Principles of rockbolting design, "Journal of Rock Mechanics and Geotechnical Engineering" 2017, 9, 3: 396-414.

[2] Pytlik A.: Tests of steel arch and rock bolt support resistance to static and dynamic loading induced by suspended monorail transportation, "Studia Geotechnica et Mechanica" 2019, 2, 41: 81-92.

[3] Pytlik A., Prusek S., Masny W.: A methodology for laboratory testing of rockbolts used in underground mines under dynamic loading conditions, "Journal of the Southern African Institute of Mining and Metallurgy" 2016, 12, 116: 1101-1110.

[4] Li C.C., Hadjigeorgiou J., Mikula P., Knox G., Darlington B., Royer R., Pytlik A., Hosp M.: Performance of identical rockbolts tested on four dynamic testing rigs employing the direct impact method, "Journal of Rock Mechanics and Geotechnical Engineering" 2021, 13, 4: 745-754.

[5] Pytlik A.: Comparative Shear Tests of Bolt Rods Under Static and Dynamic Loading, "Studia Geotechnica et Mechanica" 2020, 2, 42: 151-167.

[6] PN-EN 14490:2010: Wykonawstwo specjalnych robót geotechnicznych - Gwoździe gruntowe.

[7] PN-EN 14199:2015-07: Wykonawstwo specjalnych robót geotechnicznych - Mikropale.

[8] Cała M., Kowalski M.: Analiza stateczności skarp z gruntu zbrojonego, "Górnictwo i Geoinżynieria" 2008, 2, 32: 67-77.

[9] Furtak K., Gaszyński J., Pabian Z.: Geotechniczne systemy zabezpieczeń $i$ stabilizacji na terenach osuwiskowych, cz. 1, "Nowoczesne Budownictwo Inżynieryjne" 2011, 6, 39: 68-70.
[10] Furtak K., Gaszyński J., Pabian Z.: Geotechniczne systemy zabezpieczeń $i$ stabilizacji na terenach osuwiskowych, cz. 2, "Nowoczesne Budownictwo Inżynieryjne" 2012, 1, 40: 44-48.

[11] Majcherczyk T., Niedbalski Z., Kowalski M.: 3D numerical modeling of road tunnel stability. The Laliki project, "Archives of Mining Sciences" 2012, 1, 57: 61-78.

[12] European Assessment Document EAD: Post-tensioning kits for prestressing of structures, 2016, September: 160004-00-0301.

[13] European Assessment Document EAD: Kit for micropiles kit with hollow bars for self-drilling micropiles - hollow bars of seamples steel tubes, 2016, August: 200036-00-0103.

[14] PN-EN ISO 6892-1:2019:11: Metale - Próba rozciagania Część 1: Metoda badania w temperaturze pokojowej.

[15] Skrzypkowski K., Korzeniowski W., Herezy L.: Metody badania obudowy kotwowej $w$ Katedrze Górnictwa Podziemnego AGH, "CUPRUM - Czasopismo Naukowo-Techniczne Górnictwa Rud" 2015, 3, 76: 49-60.

[16] ASTM D7401-08: Standard Test Methods for Laboratory Determination of Rock Anchor Capacities by Pull and Drop Tests.

WITOLD FRĄC, M.Sc., Eng. ANDRZEJ PYTLIK, Ph.D., Eng. KRZYSZTOF PACZEŚNIOWSKI, Ph.D., Eng. Główny Instytut Górnictwa (Central Mining Institute) pl. Gwarków 1, 40-166 Katowice, Poland \{wfrac, apytlik, kpaczesniowski\}@gig.eu

(C) 2020 Authors. This is an open access publication, which can be used, distributed and reproduced in any medium according to the Creative Commons CC-BY 4.0 License. 
WITOLD FRACC

ANDRZEJ PYTLIK

KRZYSZTOF PACZEŚNIOWSKI

\title{
Badania wytrzymałościowe żerdzi kotwi górniczych i gruntowych przy obciążeniu statycznym i dynamicznym
}

\begin{abstract}
Do wzmacniania górotworu oraz gruntu powszechnie stosuje się różnego typu żerdzie kotwi wykonane zarówno w postaci stalowych prętów o petnym przekroju, jak i rur z gwintem na całej długości, które stuża do iniekcji spoiw płynnych. W artykule przedstawiono metodyke oraz przykładowe wyniki wytrzymałościowych badań żerdzi kotwi samowiercacych iniekcyjnych $z$ gwintem falistym R32. Tego typu żerdzie stosowane sa zarówno $w$ górnictwie podziemnym, jak i geoinżynierii, przy obciązeniu statycznym $i$ dynamicznym o charakterze impulsowym (udarowym). Przedstawiono również wyniki badań mikropali iniekcyjnych o średnicach gwintu o zarysie trapezowym z zakresu T51-T111 mm, stosowanych głównie $w$ geoinżynierii. Na podstawie norm oraz dokumentu EAD (European Assessment Document), obowiazujacego w Unii Europejskiej, $w$ artykule przedstawiono także podstawowe wymagania $w$ zakresie obciażeń zmęczeniowych, stawiane gwoździom i mikropalom iniekcyjnym stosowanym w geoinżynierii.
\end{abstract}

Słowa kluczowe: kotwie górnicze, gwoździe gruntowe, mikropale iniekcyjne, wytrzymatość na obciażenie statyczne i dynamiczne, badania zmęczeniowe

\section{WPROWADZENIE}

Do wzmacniania górotworu oraz gruntu powszechnie stosuje się różnego typu żerdzie kotwi wykonane zarówno w postaci stalowych prętów o pełnym przekroju, jak i rur z gwintem na całej długości, które służą do iniekcji spoiw płynnych. Wraz ze wzrostem eksploatacji górniczej w kopalniach głębinowych rośnie również rola obudowy kotwowej, której działanie polega głównie na wzmocnieniu i zwiększeniu samonośności górotworu. Obudowę kotwową stosuje się również w warunkach obciążeń dynamicznych wywołanych nie tylko wstrząsami górotworu i tąpaniami [1], ale również dynamicznymi oddziaływaniami środków transportu [2]. Podczas tąpnięcia kotwie narażone są głównie na dynamiczne obciążenie rozciągające [3, 4] oraz ścinające [5]. Ważną rolę w coraz większej popularności obudowy kotwowej odgrywa również czynnik ekonomiczny, ponieważ obudowa kotwowa jest tańsza od stalowej obudowy podporowej i wygodniejsza w transporcie. Współczesne kotwie charakteryzują się dużą wytrzymałością nie tylko na obciążenia statyczne, ale i na obciążenia dynamiczne o charakterze udarowym. Wymagania dotyczące wy- konawstwa robót geotechnicznych ujęte zostały w normach dotyczących gwoździ [6] i mikropali [7], które stosowane się głównie do wzmacniania gruntu [8-10], posadowienia obiektów budowlanych oraz stabilizacji tuneli [11]. Dlatego do wykonania żerdzi kotwi, nakrętek, tulei łączących oraz innych elementów stanowiących cały system wzmocnień stosuje się materiały stalowe o wysokich właściwościach mechanicznych potwierdzonych badaniami wytrzymałościowymi głównie przy obciążeniu statycznym i zmęczeniowym. $\mathrm{W}$ artykule przedstawiono metodykę oraz przykładowe wyniki wytrzymałościowych badań żerdzi kotwi samowiercących iniekcyjnych, stosowanych zarówno w górnictwie podziemnym, jak i geoinżynierii, przy obciążeniu statycznym i dynamicznym - o charakterze impulsowym (udarowym). Przedstawiono również wyniki badań mikropali iniekcyjnych, stosowanych głównie w geoinżynierii, przy obciążeniu statycznym. Na podstawie norm oraz dokumentu EAD [12, 13], obowiązującego w Unii Europejskiej, w artykule przedstawiono także podstawowe wymagania $\mathrm{w}$ zakresie obciążeń zmęczeniowych, stawiane gwoździom i mikropalom iniekcyjnym stosowanym w geoinżynierii. 


\section{METODYKA BADAŃ}

\subsection{Badania przy obciążeniu statycznym}

Podstawowymi parametrami wytrzymałościowymi żerdzi jest ich maksymalna wytrzymałość na rozciąganie $R_{m}$, górna $R_{e H}$ i dolna $R_{e L}$ granica plastyczności lub umowna granica plastyczności $R_{0,2}$, wydłużenie procentowe całkowite $A_{g t}$ przy sile maksymalnej oraz wydłużenie całkowite procentowe po rozerwaniu $A_{t}$. Badania rozciagania próbek stali, z której wykonuje się żerdzie, nie są miarodajne. Wynika to głównie $\mathrm{z}$ faktu, że podczas produkcji żerdzi na skutek procesów technologicznych ulegają również zmianom właściwości mechaniczne stali. Konieczne więc jest przeprowadzanie prób rozciągania gotowego wyrobu, to znaczy żerdzi kotwi, co dopuszcza norma PN-EN ISO 6892-1 [14]. Wyniki takich badań, choć przeprowadzonych w nieco innych warunkach, przedstawione są w pracy [15].

Badania takich żerdzi, jak również żerdzi połączonych ze sobą za pomocą łączników, przeprowadzane są w statycznej maszynie wytrzymałościowej o maksymalnej sile rozciągającej $5000 \mathrm{kN}$ (klasa dokładności 1). Na rysunku 1 został pokazany schemat badania statycznego. Badana żerdź (3) zamocowana jest między trawersami maszyny i zablokowana z każdej strony za pomocą dwóch nakrętek (2). Pomiar siły realizowany jest za pomocą czujnika siły (1) zamocowanego na trawersie stałej, a pomiar przemieszczenia jest realizowany za pomoca czujnika linkowego (4) zamocowanego do trawersy ruchomej, do której jest przyłożona siła $F_{s}$. Długość pomiarowa początko-

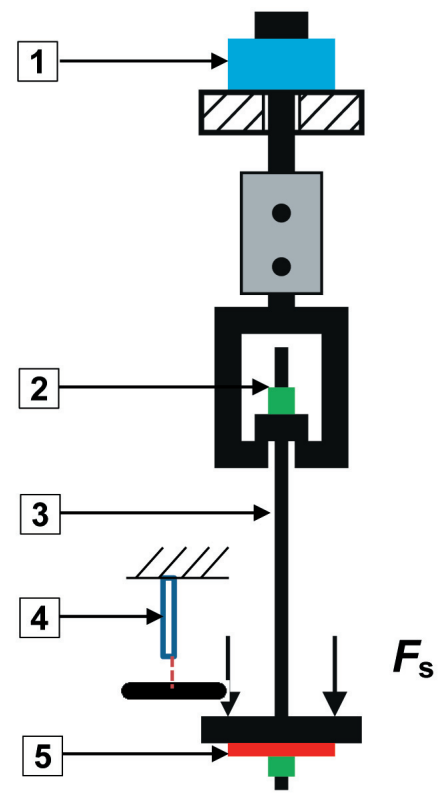

Rys. 1. Schemat obciążenia żerdzi kotwi przy obciążeniu statycznym: 1 - czujnik sity, 2 - nakrętka kotwi, 3 - żerdź kotwi, 4 - czujnik przemieszczenia, 5 - podkładka kotwi wa $L_{o}$ wynosi zwykle $1000 \mathrm{~mm}$. Badanie polega na obciążaniu badanej żerdzi siłą rozciągającą $F_{s}$, aż do momentu jej zerwania. Szybkość rozciągania określana jest na podstawie szybkości przyrostu naprężenia (metoda B w normie PN-EN ISO 6892-1 [14]), tj. 6-60 $\mathrm{MPa} \cdot \mathrm{s}^{-1}$. Podczas badania rejestrowana jest siła obciążająca $F_{s}$ oraz wydłużenie żerdzi $\Delta L$.

Parametry wytrzymałościowe żerdzi wyznaczane sa za pomoca programu komputerowego, który został opracowany i zwalidowany w Laboratorium Badań Urządzeń Mechanicznych GIG na podstawie zaleceń normy PN-EN ISO 6892-1 [14]. Program ten na podstawie danych pomiarowych zapisywanych w pliku w kodzie ASCII oraz informacji o polu poprzecznego przekroju badanej próbki $S_{o}$ i długości pomiarowej $L_{o}$ oblicza parametry wytrzymałościowe żerdzi. Wyniki przedstawiane są w postaci graficznej (wykres rozciągania) oraz tabelarycznej.

\subsection{Badania przy obciążeniu dynamicznym o charakterze udarowym}

Metoda badania kotwi według normy ASTM D7401-08 [16] przy obciążeniu dynamicznym o charakterze impulsowym (udarowym) polega na swobodnym spadku (pod wpływem siły grawitacji) bijaka o masie $m$ z określonej wysokości $h$ na końcówkę żerdzi kotwi (rys. 2). Pomiar sily realizowany jest za pomocą czujnika siły (1) zamocowanego na trawersie stałej, a pomiar przemieszczenia jest realizowany za pomoca czujnika laserowego (5) zamocowanego do podłoża mierzącego przesunięcie końcówki żerdzi kotwi.

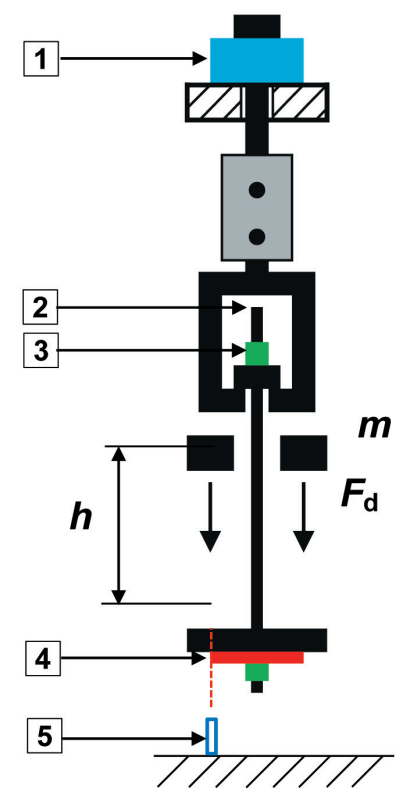

Rys. 2. Schemat obcią̇̇enia żerdzi kotwi przy obciażeniu dynamicznym o charakterze udarowym: 1 - czujnik sity, 2 - żerdź kotwi, 3 - nakrętka kotwi, 4 - podkładka kotwi, 5 - czujnik przemieszczenia 
Wynik próby uznaje się za pozytywny, jeżeli żerdź kotwi przeniesie bez zniszczenia obciążenie o określonej przez jej producenta energii i prędkości uderzenia.

Zgodnie z normą amerykańską ASTM D7401-08 [16] początkową energię uderzenia, odpowiadającą energii potencjalnej $E_{p}$ obliczamy ze wzoru:

$$
E_{p}=m g h
$$

a prędkość uderzenia $v$ w badaną kotew obliczamy ze wzoru:

$$
v=\sqrt{2 g h}
$$

gdzie:

$h$ - wysokość swobodnego spadku masy bijaka [m],

$m$ - masa bijaka $[\mathrm{kg}]$,

$$
g \text { - stała grawitacji } 9,81\left[\mathrm{~m} / \mathrm{s}^{2}\right] .
$$

Podczas badań mierzona jest dynamiczna siła obciążająca $F_{d}$ za pomocą tensometrycznego czujnika siły (klasa 0,5 ) oraz wydłużenie $L_{d}$ kotwi za pomocą czujnika laserowego (rozdzielczość $0,1 \% \mathrm{~mm}$, błąd liniowości $0,25 \%$ ) z minimalną częstotliwością próbkowania około $f=10 \mathrm{kHz}$ (wymaganie normy ASTM D7401-08 [16]). Doświadczenia Laboratorium Badań Urządzeń Mechanicznych GIG wskazują jednak, że w celu lepszego uchwycenia charakteru zmian fali obciążenia dynamicznego $F_{d}$ minimalna częstotliwość próbkowania podczas prób powinna wynosić $f=19,2 \mathrm{kHz}$. Czujniki połączone są ze wzmacniaczem pomiarowym, który współpracuje z komputerem, gdzie rejestrowane są dane pomiarowe. Wzmacniacz pomiarowy wyposażony jest w 24-bitowe przetworniki analogowo-cyfrowe, a dane pomiarowe przekazywane są w postaci 4-bajtowej (3 bajty opisujące wartość zmierzoną i 1 bajt statusu).

\subsection{Badania przy obciążeniu dynamicznym o charakterze pulsacyjnym}

Badania kotwi przy obciążeniu dynamicznym o charakterze pulsacyjnym wykonuje się na podstawie dokumentu EAD (ang. European Assessment Document) $[12,13]$. Badanie przeprowadza się w maszynie wytrzymałościowej o stałej częstotliwości obciążenia nie większej niż $30 \mathrm{~Hz}$ przy stałym obciążeniu górnym wynoszącym $65 \%$ wytrzymałości charakterystycznej żerdzi kotwi - w tym przypadku jest to siła uplastyczniająca $F_{p 0,2}$, którą uprzednio należy wyznaczyć podczas badań na rozciąganie żerdzi przy statycznym obciążeniu. Zakres obciążeń $\Delta F_{p}=F_{z \max }-F_{z \min }$ należy utrzy- mywać na stałym poziomie przez cały czas trwania badania. Odpowiada to amplitudzie naprężeń wynoszącej $80 \mathrm{MPa}$ w nominalnym przekroju poprzecznym rozciąganej żerdzi. Całe badanie składa się z 2 mln cykli obciążenia. Schemat badania pokazano na rysunku 3. Badana żerdź kotwi (3) zamocowana jest między trawersami maszyny i jest zablokowana z każdej strony za pomocą nakrętek (1). Osiowość żerdzi zapewniają podkładki kotwi (4). Pomiar siły jest realizowany za pomocą tensometrycznego czujnika siły (2).

Próbkę należy badać w taki sposób, aby wykluczyć drgania wtórne (rezonans). Również istotne jest, aby próbka nie zawierała materiału wypełniającego. Podczas badania istotne jest utrzymywanie stałej amplitudy drgań i zliczanie ilości cykli. Po badaniu należy sprawdzić stan elementów badanych, np. czy nastąpiły pęknięcia oraz odkształcenia.

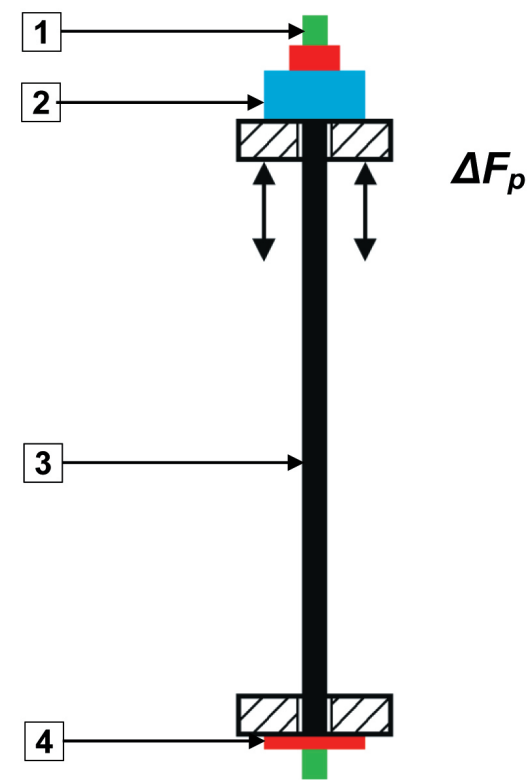

Rys. 3. Schemat obciążenia żerdzi kotwi przy obciażeniu dynamicznym o charakterze pulsacyjnym:

1 - nakrętka kotwi, 2 - czujnik sity, 3 - żerdź kotwi, 4 - podkładka kotwi

\section{WYNIKI BADAŃ}

\subsection{Wyniki badań przy obciążeniu statycznym}

Podstawowym badaniem żerdzi przy obciążeniu statycznym jest próba rozciągania. Na podstawie tej próby wyznacza się maksymalną wytrzymałość na rozciąganie $R_{m}$, górną $R_{e H}$ i dolną $R_{e L}$ granicę plastyczności lub umowną granicę plastyczności $R_{0,2}$, wydłużenie procentowe całkowite $A_{g t}$ przy sile maksymalnej oraz wydłużenie całkowite procentowe po rozerwaniu $A_{t}$. 
Badaniom przy obciążeniu statycznym poddano żerdzie kotwi z gwintem falistym R32 oraz mikropale iniekcyjne wraz z elementami złącznymi (rys. 4).

Na rysunku 5 pokazano przykładowy wykres rozciągania żerdzi górniczych kotwi samowiercących R32 przy obciążeniu statycznym.

Żerdź kotwi uległa zerwaniu przy sile $F_{\text {smax }}=366 \mathrm{kN}$. Na rysunkach 6-8 pokazano przykładowe wykresy rozciągania żerdzi mikropali iniekcyjnych T51, T76 oraz T111 przy obciążeniu statycznym.

Przykładowe zdjęcia stalowej żerdzi z łącznikiem i nakrętkami w maszynie wytrzymałościowej o zakresie $5000 \mathrm{kN}$ podczas badania wytrzymałości na rozciąganie przy obciążeniu statycznym przedstawiono na rysunku 9. Łącznik pozwala na łączenie ze sobą żerdzi kotwi celem jej przedłużenia. Na rysunku 10 pokazano żerdź kotwi po próbie rozciągania.

a)

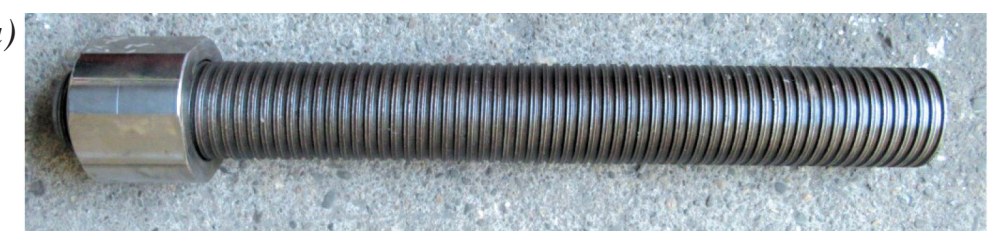

b)

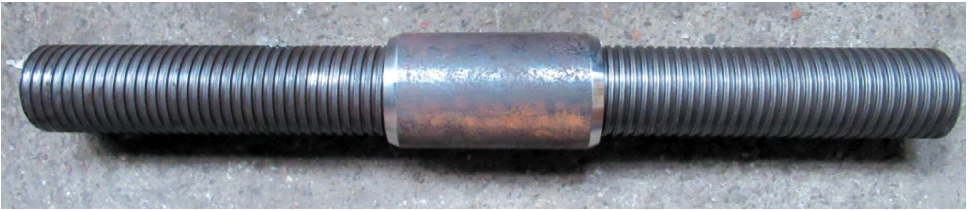

Rys. 4. Przykładowy widok mikropala iniekcyjnego z nakrętka (a) oraz dwóch odcinków mikropali połaczonych ze sobq za pomoca tacznika (b)

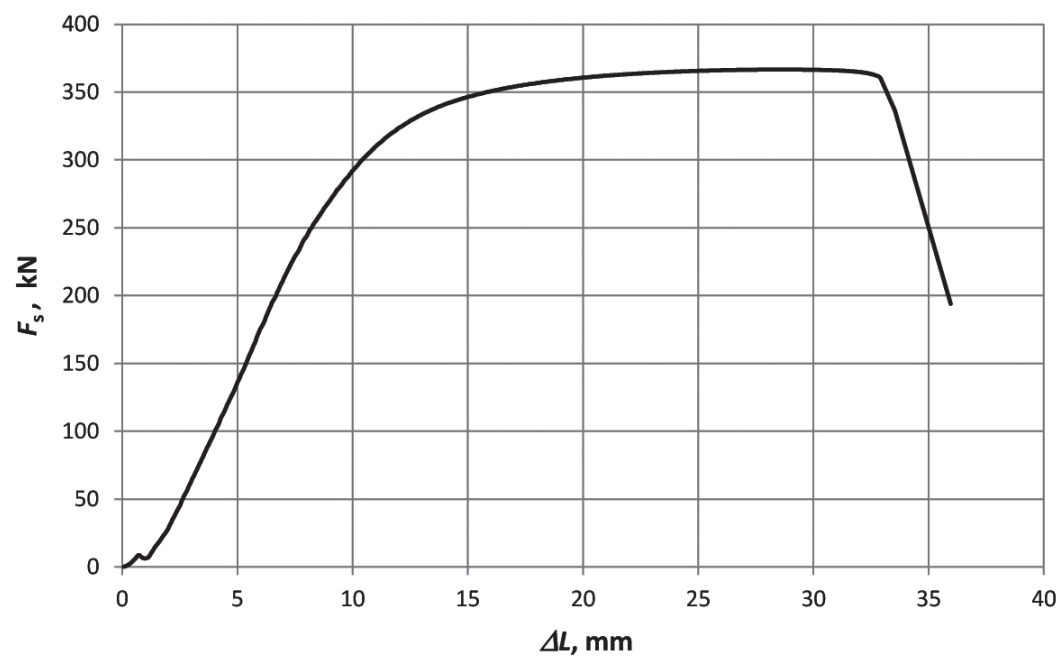

Rys. 5. Wykres rozciagania żerdzi kotwi $R 32$

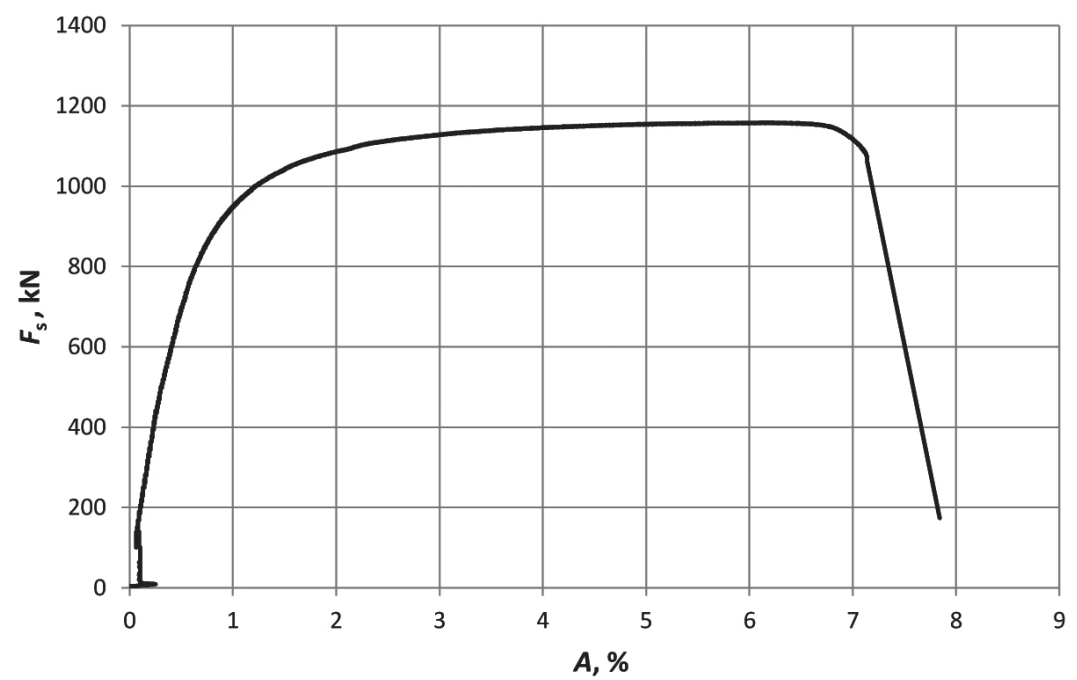

Rys. 6. Wykres rozciagania żerdzi kotwi T51 $\left(F_{\text {smax }}=1159 \mathrm{kN} ; A_{g t}=6,2 \%\right)$ 


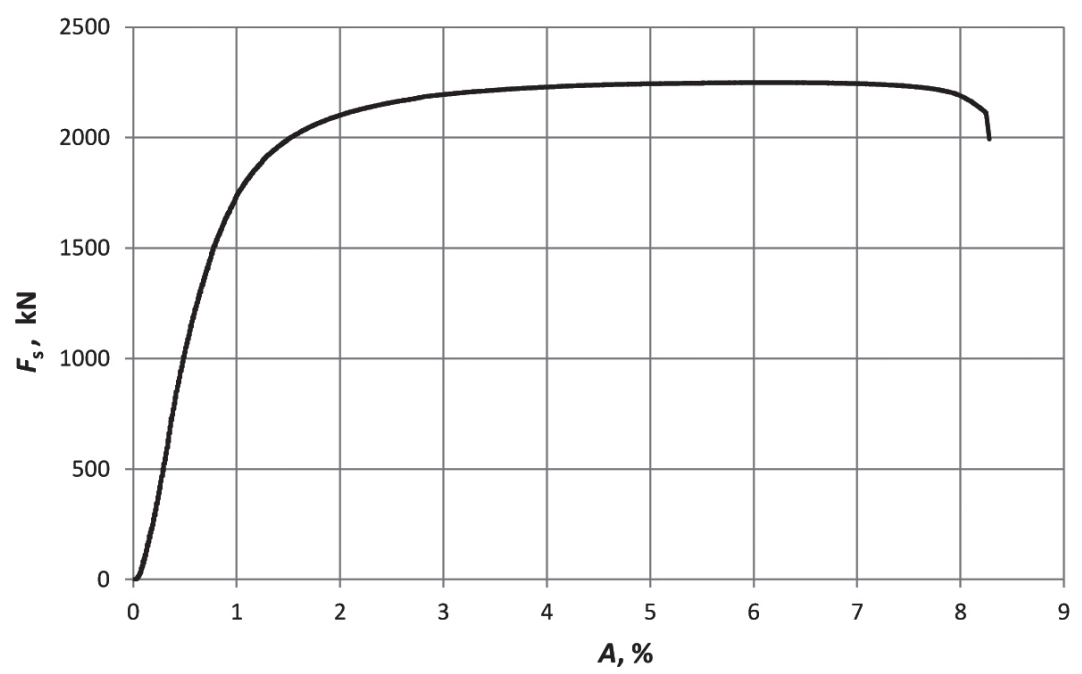

Rys. 7. Wykres rozciagania żerdzi kotwi $T 76\left(F_{\text {smax }}=2250 \mathrm{kN} ; A_{g t}=6,0 \%\right)$

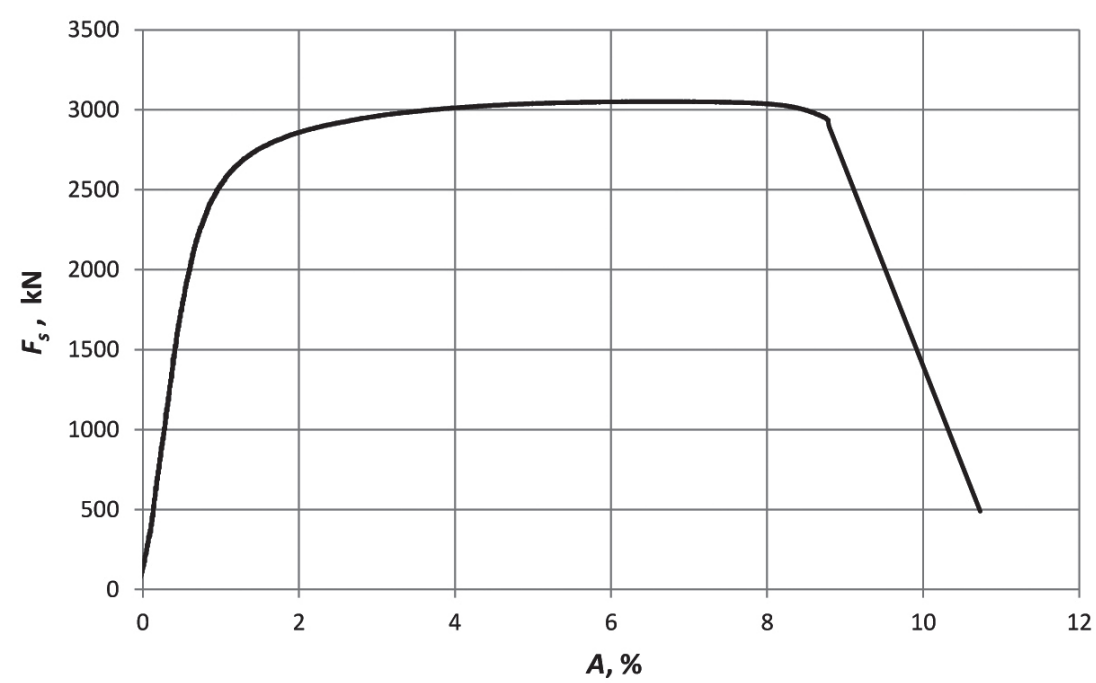

Rys. 8. Wykres rozciagania żerdzi kotwi T111 $\left(F_{\text {smax }}=3052 \mathrm{kN} ; A_{g t}=6,4 \%\right)$

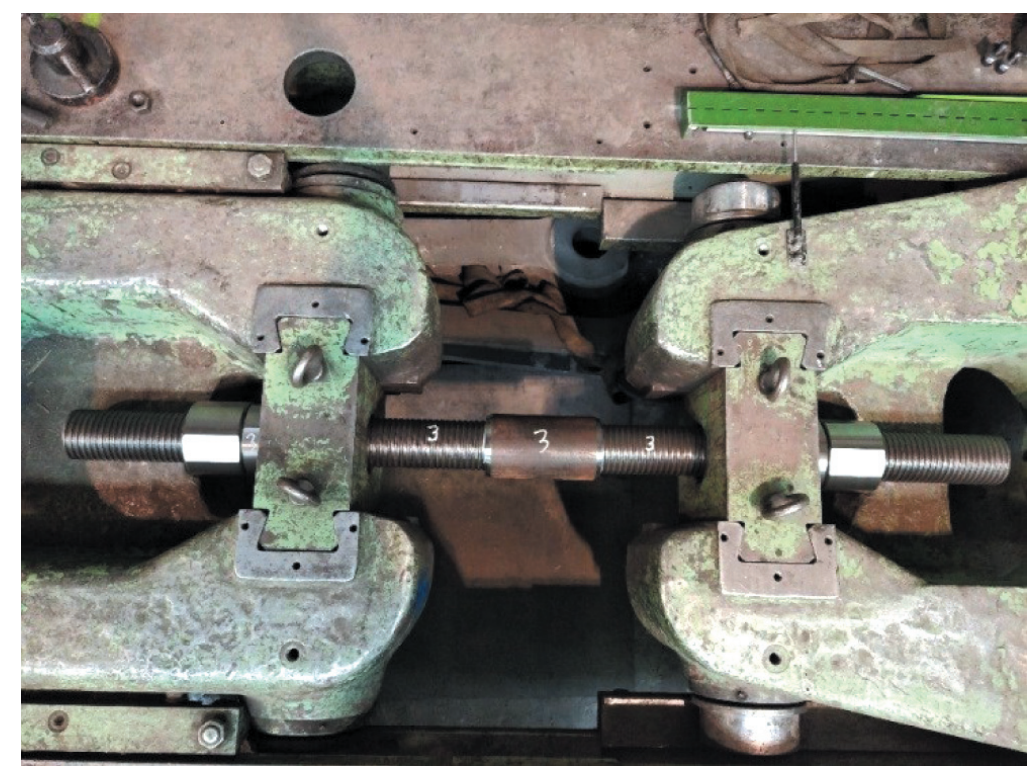

Rys. 9. Badanie wytrzymałości na rozciaganie żerdzi z tącznikiem w maszynie wytrzymałościowej o zakresie $5000 \mathrm{kN}$ 


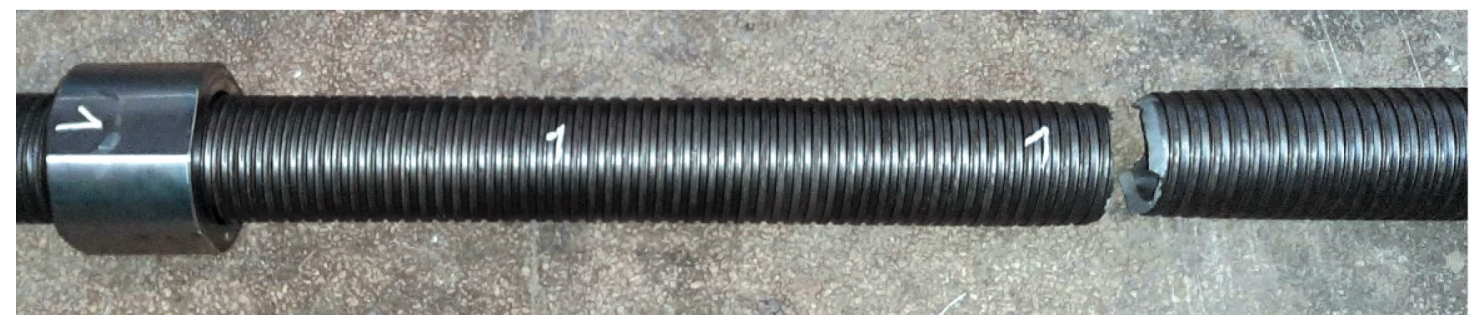

Rys. 10. Zerwana żerdź kotwi T111 po próbie rozciagania

\subsection{Wyniki badań przy obciążeniu dynamicznym o charakterze udarowym}

Badaniom poddano kotwie samowiercące $\mathrm{z}$ gwintem falistym R32, wyposażone $\mathrm{w}$ stalowe podkładki kwadratowe o wymiarach $200 \mathrm{~mm} \times 200 \mathrm{~mm} \times 12 \mathrm{~mm}$. Sprawdzano odporność żerdzi kotwi na obciążenie o energii uderzenia $E_{p}=30 \mathrm{~kJ}$ i prędkości uderzenia $5,5 \mathrm{~m} / \mathrm{s}$ (parametry badania obliczane są wg wzorów (1) i (2)). Podczas badań użyto bijaka o masie $m=1950 \mathrm{~kg}$, który opuszczany był na kotew $\mathrm{z}$ wysokości $h=1560 \mathrm{~mm}$, co powodowało, że kotew uderza- na była z prędkością $v=5,5 \mathrm{~m} / \mathrm{s}$. Przykładowy przebieg dynamicznej sily $F_{d}$ w funkcji czasu $t$ uzyskany podczas próby przedstawiono na rysunku 11 .

Kotew bez zniszczenia przeniosła obciążenie dynamiczne o charakterze impulsowym, którego energia wyniosła $30 \mathrm{~kJ}$. Na rysunku 11a widoczne są drgania gasnące spowodowane odbiciami bijaka od podkładki kotwi. Na rysunku $11 \mathrm{~b}$ widoczny jest pierwszy impuls obciążenia, podczas którego żerdź kotwi poddana została maksymalnemu obciążeniu o wartości $F_{d \max }=410 \mathrm{kN}$, a żerdź kotwi uległa maksymalnemu wydłużeniu o wartości $L_{d \max }=119 \mathrm{~mm}$.

a)

b)

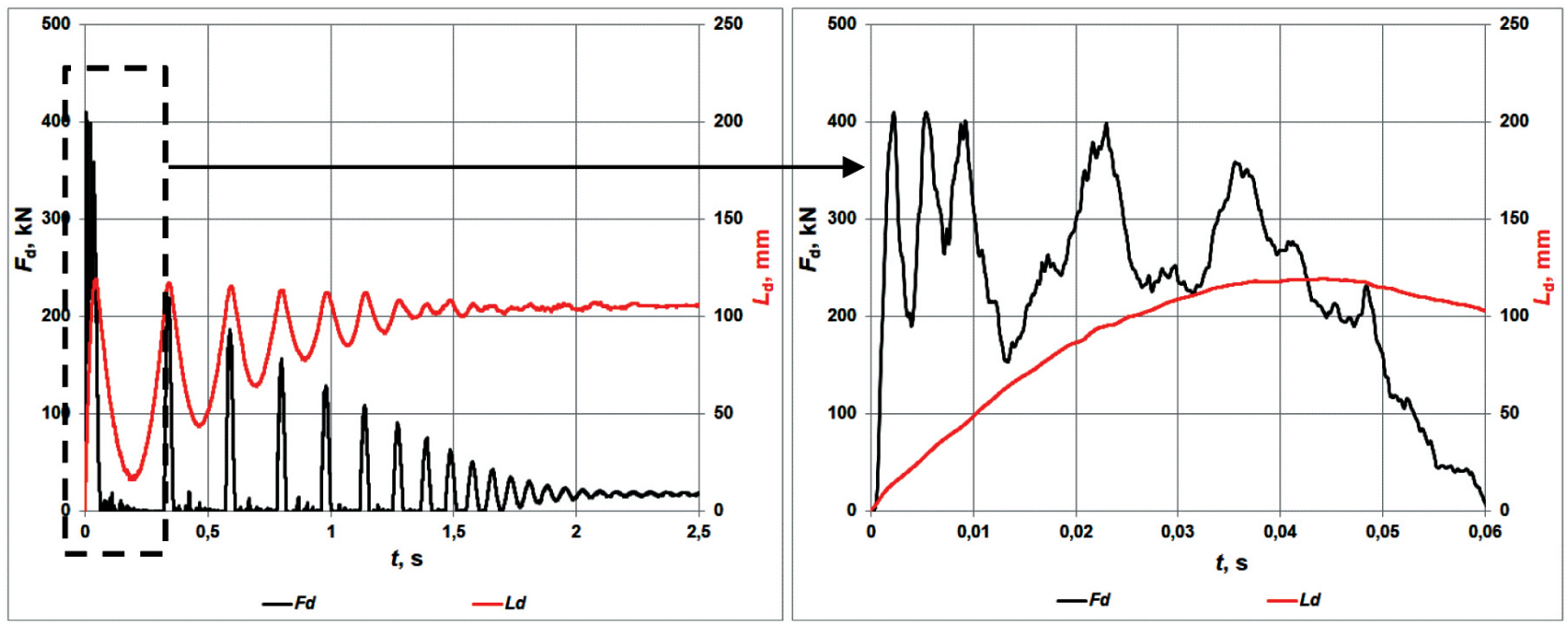

Rys. 11. Przykładowy przebieg dynamicznej sity $F_{d} w$ funkcji czasu t uzyskany podczas próby:

a) petny przebieg próby; b) pierwszy impuls obciązenia

Pozostałe impulsy obciążenia wynikające z kolejnych niewielkich odbić bijaka od podkładki kotwi, nie powodują odkształcenia plastycznego żerdzi, dlatego nie są poddawane analizie.

\subsection{Wyniki badań przy obciążeniu dynamicznym o charakterze pulsacyjnym}

Badaniom przy obciążeniu dynamicznym o charakterze pulsacyjnym poddano żerdzie kotwi z gwintem falistym R25. Jej nominalna siła uplastyczniająca
$F_{p 0,2}$ wynosi $150 \mathrm{kN}$, a nominalne pole powierzchni przekroju $S_{o}$ wynosi $300 \mathrm{~mm}^{2}$. Maksymalna siła pulsacji wynosi $65 \%$ z $F_{p 0,2}$, czyli $97,5 \mathrm{kN}$ przy amplitudzie pulsacji $24 \mathrm{kN}$. Podczas próby częstotliwość pulsacji wynosiła powyżej $10 \mathrm{~Hz}$. Przykładowe zdjęcia stalowej żerdzi w maszynie wytrzymałościowej podczas badania pulsacyjnego przedstawiono na rysunku 12 , a przykładowy przebieg pulsacyjnej siły $F_{z}$ w funkcji czasu $t$ uzyskany podczas próby przedstawiono na rysunku 13. Żerdź kotwi po próbie nie wykazywała żadnych widocznych wad ani pęknięć. 


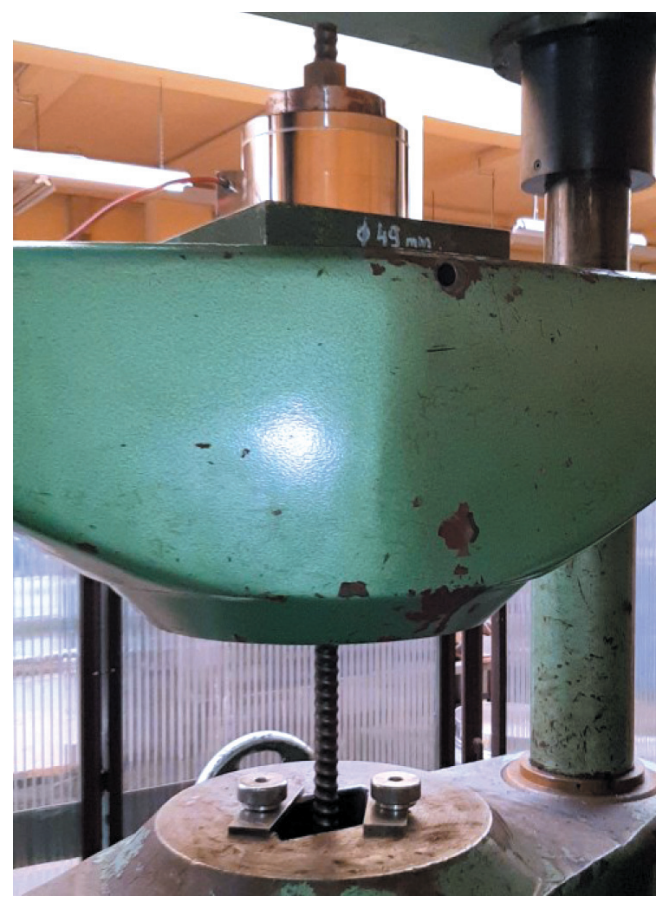

Rys. 12. Żerdź kotwi zamocowana w pulsacyjnej maszynie wytrzymatościowej

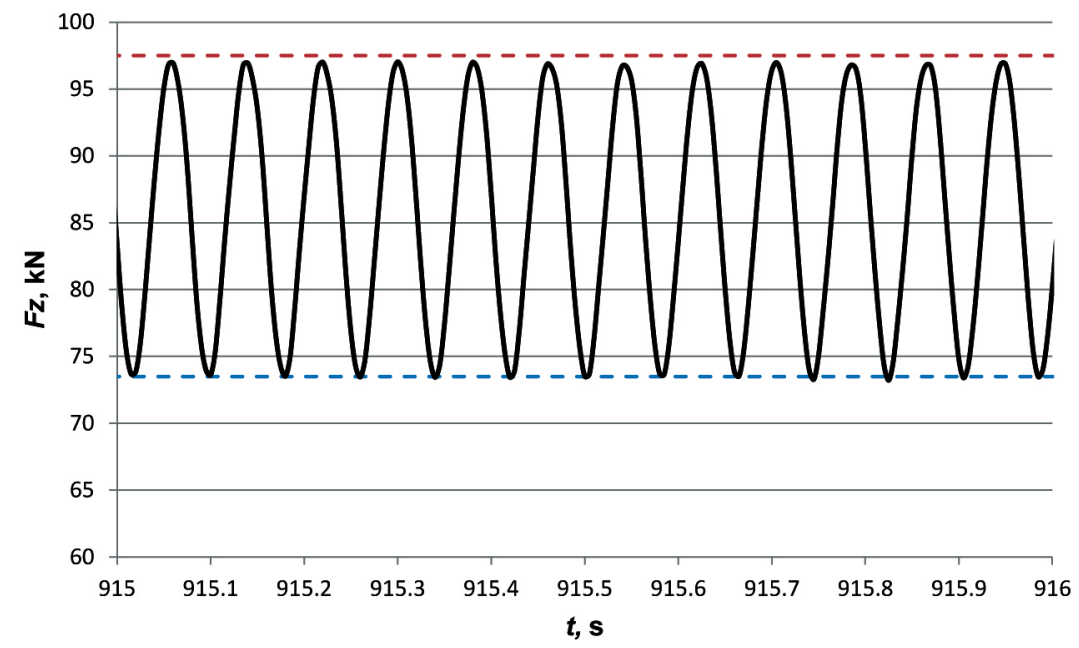

Rys. 13. Przykładowy przebieg pulsacyjnej siły $F_{z}$ w funkcji czasu t uzyskany podczas próby

\section{PODSUMOWANIE}

Przedstawione w artykule metody badań kotwi samowiercących iniekcyjnych z gwintem falistym R32 oraz mikropali iniekcyjnych o trapezowym zarysie gwintu z zakresu T51-T111 mm uwzględniają typową specyfikę pracy kotwi w różnych warunkach ich stosowania. Standardowo wykonuje się badania tych elementów przy obciążeniu statycznym, ale w czasie eksploatacji kotwi, mikropali i gwoździ gruntowych mogą się zdarzyć różne przypadki ich obciążenia. Badania mikropali i gwoździ gruntowych przy dynamicznym obciążeniu o charakterze zmęczeniowym są bardzo ważne dla określenia ich wytrzymałości na długotrwałe obciążenia cykliczne. Wydaje się jednak, że ze względu na to, że są one stosowane często do stabilizacji obiektów infrastruktury krytycznej, powinno się wziąć pod uwagę fakt, że mogą one być również poddane obciążeniom udarowym, indukowanym, np. przez trzęsienia ziemi lub wstrząsy na terenach górniczych i pogórniczych.

Działania Głównego Instytutu Górnictwa zmierzają do tego, aby poprawić bezpieczeństwo ludzi oraz warunki ich pracy nie tylko w podziemiach kopalń, ale również na terenach pogórniczych, na których występują duże problemy $\mathrm{z}$ utrzymaniem stabilizacji nasypów, skarp, dróg oraz innych obiektów inżynierskich. Dlatego planuje się rozszerzenie badań mikropali i gwoździ gruntowych, w tym również o badania zmęczeniowe i udarowe. 


\section{Literatura}

[1] Li C.C.: Principles of rockbolting design, „Journal of Rock Mechanics and Geotechnical Engineering" 2017, 9, 3: 396-414.

[2] Pytlik A.: Tests of steel arch and rock bolt support resistance to static and dynamic loading induced by suspended monorail transportation, „Studia Geotechnica et Mechanica” 2019, 2, 41: 81-92.

[3] Pytlik A., Prusek S., Masny W.: A methodology for laboratory testing of rockbolts used in underground mines under dynamic loading conditions, ,Journal of the Southern African Institute of Mining and Metallurgy" 2016, 12, 116: 1101-1110.

[4] Li C.C., Hadjigeorgiou J., Mikula P., Knox G., Darlington B., Royer R., Pytlik A., Hosp M.: Performance of identical rockbolts tested on four dynamic testing rigs employing the direct impact method, „Journal of Rock Mechanics and Geotechnical Engineering" 2021, 13, 4: 745-754.

[5] Pytlik A.: Comparative Shear Tests of Bolt Rods Under Static and Dynamic Loading, „Studia Geotechnica et Mechanica” 2020, 2, 42: 151-167.

[6] PN-EN 14490:2010: Wykonawstwo specjalnych robót geotechnicznych - Gwoździe gruntowe.

[7] PN-EN 14199:2015-07: Wykonawstwo specjalnych robót geotechnicznych - Mikropale.

[8] Cała M., Kowalski M.: Analiza stateczności skarp z gruntu zbrojonego, „Górnictwo i Geoinżynieria” 2008, 2, 32: 67-77.

[9] Furtak K., Gaszyński J., Pabian Z.: Geotechniczne systemy zabezpieczeń $i$ stabilizacji na terenach osuwiskowych, cz. 1, „Nowoczesne Budownictwo Inżynieryjne” 2011, 6, 39: 68-70.
[10] Furtak K., Gaszyński J., Pabian Z.: Geotechniczne systemy zabezpieczeń $i$ stabilizacji na terenach osuwiskowych, cz. 2, „Nowoczesne Budownictwo Inżynieryjne” 2012, 1, 40: 44-48.

[11] Majcherczyk T., Niedbalski Z., Kowalski M.: 3D numerical modeling of road tunnel stability. The Laliki project, „Archives of Mining Sciences" 2012, 1, 57: 61-78.

[12] European Assessment Document EAD: Post-tensioning kits for prestressing of structures, 2016, September: 160004-00-0301.

[13] European Assessment Document EAD: Kit for micropiles kit with hollow bars for self-drilling micropiles - hollow bars of seamples steel tubes, 2016, August: 200036-00-0103.

[14] PN-EN ISO 6892-1:2019:11: Metale - Próba rozciagania Część 1: Metoda badania w temperaturze pokojowej.

[15] Skrzypkowski K., Korzeniowski W., Herezy Ł: Metody badania obudowy kotwowej w Katedrze Górnictwa Podziemnego $A G H$, „CUPRUM - Czasopismo Naukowo-Techniczne Górnictwa Rud" 2015, 3, 76: 49-60.

[16] ASTM D7401-08: Standard Test Methods for Laboratory Determination of Rock Anchor Capacities by Pull and Drop Tests.

mgr inż. WITOLD FRĄC

dr inz. ANDRZEJ PYTLIK

dr inż. KRZYSZTOF PACZEŚNIOWSKI

Gtówny Instytut Górnictwa

pl. Gwarków 1, 40-166 Katowice

\{wfrac, apytlik, kpaczesniowski\}@gig.eu

(C) 2020 Autorzy. Jest to publikacja ogólnodostępna, którą można wykorzystywać, rozpowszechniać i kopiować w dowolnej formie zgodnie z licencją Creative Commons CC-BY 4.0. 